\title{
Pengaruh Asam Alfa Lipoat Terhadap Kadar Trigliserida pada Tikus Diabetes Melitus Tipe 2
}

\author{
Angel Chen, ${ }^{1 *}$ Ismawati, $^{2}$ Enikarmila Asni ${ }^{2}$
}

\begin{abstract}
Accumulation of triglycerides associated with insulin resistance in type 2 diabetes mellitus (T2DM). Alpha lipoic acid (ALA) has hypotriglyceridemic effects by lowering triglyceride levels in blood and liver. This study aimed to analyze effect of ALA on triglyceride levels in type 2 diabetic rats. Fifteen Wistar male rats ( $\pm 8-12$ weeks, 200-250 gram) divided into 3 groups (control, T2DM and T2DM-ALA given for 3 weeks). Diabetes was induced by giving streptozotocin (50 $\mathrm{mg} / \mathrm{kg} . \mathrm{bw}$ ) and nicotinamide (110 mg/kg.bw) after 15 minutes intraperitoneally. Diagnosis of T2DM was determined if the rats have perifer blood glucose $>250 \mathrm{mg} / \mathrm{dL}$ after 3 days. The results showed that triglyceride levels in ALA group ( $p=0,003$ ) lower than T2DM group, T2DM group $(p=0,031)$ had higher triglyceride level than control and no difference of triglyceride level between T2DM-ALA given group with control $(p=0,696)$. This study concluded that ALA can affect triglyceride levels in T2DM thus prevents occurrence of hypertriglyceridemia.
\end{abstract}

Keywords: alpha lipoic acid, triglyceride, type 2 diabetes mellitus, streptozotocin, nicotinamid

Diabetes melitus (DM) tipe 2 sudah menjadi masalah kesehatan dunia dengan 382 juta orang (8,3\% populasi dunia) didiagnosis menderita penyakit ini di tahun 2013. Prevalensi DM tipe 2 akan terus meningkat pada 20 tahun ke depan dan diprediksi 592 juta orang (10,1\% populasi dunia) akan menderita penyakit ini di tahun 2035. ${ }^{1}$ Berdasarkan data Riskesda tahun 2013, prevalensi penderita DM tipe 2 di Indonesia sebesar 2,1\%. ${ }^{2}$

Diabetes melitus memiliki beberapa komplikasi yang mungkin terjadi jika tidak ditatalaksana dengan baik yaitu adipositas, hipertensi, dislipidemia, dan peningkatan agregasi platelet dalam darah sehingga memberikan peningkatan risiko kerusakan makrodan mikrovaskular dan menurunkan harapan hidup. ${ }^{3}$ Mihardja et al menyatakan prevalensi DM tipe 2 yang disertai keadaan dislipidemia pada penduduk Indonesia yang berusia produktif dan tinggal di wilayah perkotaan lebih dari 50\%. ${ }^{4}$ Pada pasien DM tipe 2 yang mengalami keadaan dislipidemia dapat disertai peningkatan kadar trigliserida. Soebardi et al, menunjukkan prevalensi hipertrigliseridemia sebesar 54,3\% pada pasien yang baru didiagnosis
DM tipe 2 dan bahkan kadar trigliserida akan semakin meningkat pada kelompok pasien yang tidak terkontrol. ${ }^{5}$

Alpha Lipoic Acid (ALA) atau asam alfa lipoat memiliki kemampuan sebagai antioksidan biologi dan suplemen DM untuk hipertrigliseridemia. Beberapa penelitian pada hewan coba mengindikasikan ALA memiliki efek hipotrigliseridemik sehingga menurunkan kadar trigliserida darah dan hati, serta menurunkan masa lemak di abdomen. ${ }^{6}$ Penelitian Butler et al menunjukkan penurunan kadar trigliserida hati pada model tikus Zucker Diabetic Fatty yang diberi ALA (200 mg/kgbb/hari) selama 5 minggu. ${ }^{7}$ Pada manusia, penelitian oleh Heinisch et al, menunjukkan penurunan HbA1c, kolesterol total, dan trigliserida pada pasien diabetes melitus tipe 2 yang diberi suplementasi ALA (600 mg) secara intravena selama 21 hari. ${ }^{8}$ Dengan demikian, ALA dapat menurunkan kadar trigliserida sehingga memiliki potensi sebagai terapi pencegahan hipertrigliseridemia dan dislipidemia pada diabetes melitus. ${ }^{7}$

\footnotetext{
* Penulis untuk korespondensi :angelcheneviez@gmail.com

${ }^{1}$ Fakultas Kedokteran Universitas Riau

${ }^{2}$ KJF Biokimia Fakultas Kedokteran Universitas Riau
} 


\section{METODE}

Penelitian ini menggunakan desain penelitian post test only with control. Tikus Wistar jantan $( \pm 8-$ 12 minggu, 200-250 gram) sebanyak 15 ekor dibagi menjadi 3 kelompok (kontrol, DM tipe 2, DM tipe 2 yang diberi ALA). Kelompok kontrol dan DM tipe 2 diberikan diet standar berupa makan pelet Vivo 512 dan minum air sepuasnya. Kelompok DM tipe 2 yang diberikan ALA mendapatkan diet standar dan ALA (T5625-5G, $60 \mathrm{mg} / \mathrm{kgbb}$ ) secara sonde lambung. ${ }^{9}$ Tikus yang dipuasakan 12 jam sebelumnya dinduksi diabetes melitus dengan memberikan streptozotosin (50130-1G, 50 mg/kgbb, dilarutkan dengan buffer sitrat $0,1 \mathrm{M} \mathrm{pH} 4,5$ ) secara intraperitoneal dan 15 menit kemudian dilanjutkan dengan pemberian nikotinamid (47865-U, $110 \mathrm{mg} / \mathrm{kgbb}$ ) secara intraperitoneal. ${ }^{10}$ Tikus didiagnosis DM jika gula darah perifer $>250 \mathrm{mg} / \mathrm{dL}$ setelah 3 hari. Pada minggu ketiga, tikus dikorbankan dengan menggunakan eter. Pengambilan darah dilakukan dengan mengaspirasi langsung hemitoraks kiri menggunakan spuit yang dibilas heparin. Darah kemudian disentrifugasi dengan kecepatan 1500 rpm selama 5 menit untuk memperoleh plasma. Plasma selanjutnya disimpan dalam lemari pendingin $-20^{\circ} \mathrm{C}$ sampai waktu pemeriksaan. Pemeriksaan trigliserida dilakukan dengan metode colorimetric enzymatic test menggunakan glycerol-3-phosphate-oxidase (GPO). Analisa data penelitian menggunakan metode One Way Anova dan dilanjutkan dengan uji post hoc-bonferroni.

\section{HASIL}

Penelitian tentang pengaruh asam alfa lipoat terhadap kadar trigliserida tikus diabetes melitus tipe 2 yang dilakukan di Laboratorium Biokimia Fakultas Kedokteran Universitas Riau dan Laboratorium Kesehatan Daerah Pekanbaru menggunakan 15 ekor tikus Wistar jantan mendapatkan hasil sebagai berikut (Tabel 1).

Tabel 1. Kadar trigliserida tikus terhadap perlakuan

\begin{tabular}{cccc}
\hline & \multicolumn{3}{c}{ Perlakuan } \\
\cline { 2 - 4 } Ulangan & Kontrol & DM tipe 2 & DM tipe 2 + ALA \\
\hline 1 & 34 & 68 & 37 \\
\hline 2 & 46 & 69 & 38 \\
\hline 3 & 46 & 81 & 38 \\
\hline 4 & 57 & 137 & 46 \\
\hline 5 & 90 & 205 & $51,8 \pm 1,64$ \\
\hline
\end{tabular}

Berdasarkan Tabel 1, didapatkan rata-rata kadar trigliserida dari masing-masing kelompok dan jika diurutkan dari yang tertinggi ke terendah didapatkan hasil sebagai berikut : kelompok DM tipe $2(112,00 \pm 59,20)$, kelompok kontrol $(54,60 \pm 21,39)$, dan kelompok DM tipe $2+$ ALA $(41,8 \pm 1,64)$.

Data hasil penelitian diolah menggunakan metode One Way Anova yang dilanjutkan dengan uji post hoc-bonferroni. Data hasil penelitian terdistribusi normal dengan menggunakan ShapiroWilk dimana didapatkan $\mathrm{p}=0,287(\mathrm{p}>0,05)$ setelah dilakukan transformasi data berupa inverse dari kadar trigliserida. Kemudian dilakukan uji homogenitas pada data hasil penelitian dan didapatkan $p=0,074(p>0,05)$, maka varians data antar kelompok sama. Selanjutnya untuk menguji hipotesis dilakukan uji One Way Anova yang dilanjutkan dengan post-hoc bonferroni. Adapun hasil analisis One Way Anova disajikan pada Tabel 2. 
Tabel 2. Hasil analisis One Way Anova

\begin{tabular}{ccccc}
\hline & & $\mathrm{n}$ & Rerata \pm SD & $p$ \\
\hline \multirow{2}{*}{$\begin{array}{c}\text { Kadar } \\
\text { Trigliserida }\end{array}$} & Kontrol & 5 & $0,02 \pm 0,006$ & \\
\cline { 2 - 4 } 0 & DM tipe 2 & 5 & 0,001 \\
\cline { 2 - 4 } & DM tipe 2 + ALA & 5 & $0,01 \pm 0,004$ & \\
\hline
\end{tabular}

Pada uji One Way Anova, didapatkan p = 0,001 . Karena nilai $\mathrm{p}<0,05$ maka terdapat perbedaan yang bermakna rerata kadar antar kelompok. Untuk

melihat apakah ada perbedaan yang bermakna antar kelompok, dilanjutkan dengan analisis post hocbenferroni pada Tabel 3.

Tabel 3. Hasil analisis post hoc-bonferroni

\begin{tabular}{|c|c|c|c|c|}
\hline & \multirow{2}{*}{$\begin{array}{l}\text { Perbedaan } \\
\text { rata-rata }\end{array}$} & \multicolumn{2}{|c|}{ IK 95\% } & \multirow[b]{2}{*}{$p$} \\
\hline & & Minimum & Maximum & \\
\hline DM tipe 2 vs kontrol & $-0,009$ & $-0,017$ & $-0,001$ & 0,022 \\
\hline DM tipe 2 vs DM tipe $2+$ ALA & $-0,015$ & $-0,023$ & $-0,006$ & 0,001 \\
\hline Kontrol vs DM tipe $2+$ ALA & $-0,005$ & $-0,013$ & 0,002 & 0,263 \\
\hline
\end{tabular}

IK : Interval kepercayaan

Ditemukan adanya perbedaan bermakna $(\mathrm{p}<$ 0,05 ) antara kelompok DM tipe 2 dengan kelompok kontrol dan kelompok DM tipe 2 dengan kelompok DM tipe $2+$ ALA. Kelompok kontrol dengan DM tipe $2+$ ALA tidak ditemukan perbedaan bermakna. Berdasarkan uji hipotesis yang dilakukan $(p<0,05)$ maka terdapat pengaruh pemberian asam alfa lipoat terhadap kadar trigliserida pada tikus jantan yang diinduksi diabetes melitus tipe 2 .

\section{PEMBAHASAN}

\section{Peningkatan kadar trigliserida pada tikus diabetes melitus tipe 2}

Diabetes melitus tipe 2 pada manusia ditandai dengan keadaan gangguan sekresi insulin yang distimulasi dengan glukosa. Pada tikus yang diinduksi menggunakan STZ (agen diabetogenik poten yang menyebabkan kerusakan dari sel beta pankreas) dan dilanjutkan dengan penyuntikan nikotinamid yang dapat melindungi sel beta dari sitotoksisitas STZ, akan memberikan karakteristik tikus diabetes melitus tipe $2 .{ }^{11}$

Karakteristik dari tikus diabetes melitus tipe 2 adalah hiperglikemia yang stabil dan tidak memerlukan insulin eksogen untuk bertahan hidup, pengurangan jumlah sel beta pankreas sampai $40 \%$, pengurangan jumlah insulin pankreas sebanyak 60\%, intoleransi glukosa akibat dari gangguan sekresi insulin, memberikan respon terhadap pemberian sulfonilurea ( tolbutamid dan glibenklamid), polifagi, dan polidipsi. Dengan karakteristik ini, model tikus diabetes yang diinduksi STZ-nikotinamid cocok digunakan sebagai hewan coba untuk melihat efektifitas agen anti-diabetik baru yang potensial dan mempelajari komplikasi dari diabetes melitus tipe $2 .{ }^{12}$

Pada penelitian ini, kadar trigliserida pada tikus DM tipe 2 (kelompok II) secara signifikan $(\mathrm{p}<0.05$ ) memiliki rata-rata lebih tinggi dibandingkan dengan tikus kontrol (kelompok I). Hal ini menunjukkan bahwa terjadi kenaikan kadar trigliserida lebih dari normal pada kelompok tikus DM tipe 2 jika dibandingkan dengan tikus kontrol. Keadaan ini dapat disebabkan oleh kekurangan jumlah insulin dan resistensi insulin yang menyebabkan terjadinya penurunan fungsi insulin sehingga menghambat proses lipolisis. Hal ini akan menyebabkan peningkatan pembentukan asam lemak bebas, penurunan aktivitas lipoprotein lipase, dan peningkatan sekresi VLDL. ${ }^{13}$ Peningkatan mobilisasi asam lemak bebas dari penyimpanannya di perifer juga dapat menyebabkan peningkatan trigliserida pada keadaan resistensi insulin. ${ }^{14}$ 
Beberapa penelitian juga menunjukkan terjadinya peningkatan trigliserida pada tikus DM tipe 2 yang diinduksi STZ-nikotinamid. Penelitian Satheesh et al menggunakan tikus Wistar jantan yang diinduksi STZ (65 mg/kgbb) dan nikotinamid (110 mg/kgbb) secara intraperitoneal menjadi tikus DM tipe 2 menunjukkan peningkatan kadar trigliserida sampai 40\% dibandingkan dengan tikus kontrol setelah 6 minggu. ${ }^{15}$ Nekooeian et al juga menginduksi tikus Sprague-Dawley jantan dengan STZ (65 mg/kgbb) dan nikotinamid (100 mg/kgbb) secara intraperitoneal menjadi tikus DM tipe 2 menunjukkan kadar trigliserida yang lebih tinggi dibandingkan tikus normal. ${ }^{16}$ Pada penelitian ini, kelompok tikus DM tipe 2 yang diinduksi STZnikotinamid sudah menunjukkan peningkatan kadar trigliserida rata-rata lebih tinggi 51\% dari kelompok tikus kontrol hanya dalam waktu 3 minggu.

\section{Penurunan kadar trigliserida oleh kerja asam alfa lipoat}

Beberapa penelitian pada hewan coba menunjukkan bahwa ALA memiliki efek hipotrigliseridemik melalui penurunan kadar trigliserida di darah dan hati, serta penurunan masa lemak di abdomen. Pemberian ALA pada tikus menurunkan regulasi enzim utama yang terlibat dalam proses lipogenesis, terutama di hati dan jaringan adiposa, dimana secara bersamaan meningkatkan proses katabolisme asam lemak di hati dan otot skelet. ${ }^{6}$ Pada penelitian ini, kadar trigliserida pada tikus DM tipe 2 yang diberi ALA (kelompok III) secara signifikan $(p<0,05)$ memiliki rata-rata lebih rendah dibandingkan kadar trigliserida pada tikus DM tipe 2 (kelompok II), hal ini menunjukkan bahwa ALA dapat menurunkan kadar trigliserida pada tikus DM tipe 2. Selanjutnya hasil penelitian menunjukkan tidak ada perbedaan signifikan antara tikus DM tipe 2 yang diberi ALA (kelompok III) dengan tikus kontrol $(\mathrm{p}=0,696)$, dengan demikian ALA dapat mempengaruhi kadar trigliserida pada tikus DM tipe 2 sampai sama dengan kadar trigliserida kontrol.

Asam alfa lipoat memiliki beberapa mekanisme kerja dalam menurunkan trigliserida. Asam alfa lipoat dapat menurunkan ekspresi gen lipogenik di hati sehingga menurunkan kadar enzim sintesis trigliserida. Enzim yang dimaksudkan adalah GPAT1 (sn-glycerol-3-phosphate acyltransferase-1) dan DGAT-2 (diacylglycerol O-acyltransferase2). Penelitian Hammond et al menunjukkan tikus yang kekurangan enzim ini akan memberikan gambaran penurunan kadar trigliserida di hati sampai $40 \%$, penurunan kadar trigliserida di darah, penurunan sekresi VLDL, dan gonadal fats pad menjadi lebih ringan sampai $30 \% .{ }^{17}$

Mekanisme ALA menurunkan enzim ini adalah dengan menurunkan ChREBP (carbohydrate responsive element binding protein) dan SREBP1C (sterol regulatory element binding protein 1-c), protein penginduksi lipogenesis dan faktor transkripsi dari beberapa enzim anabolisme lipid termasuk GPAT-1 dan DGAT-2. ${ }^{6}$ Penurunan ChREBP oleh ALA berhubungan dengan penurunan ekspresi gen L-PK (liver-type pyruvate kinase), gen yang berada dibawah kontrol ChREBP. Penurunan regulasi SREBP1-c di sel hepar terjadi karena ALA memediasi insulin-induced gene 2 protein (INSIG2) yang bekerja menghambat aktivasi SREBP1-c. ${ }^{6}$ Maka penurunan ChREBP dan SREBP1-c di hati menyebabkan penurunan enzim lipogenesis sehingga ini menjadi penjelasan ALA dapat menurunkan trigliserida.

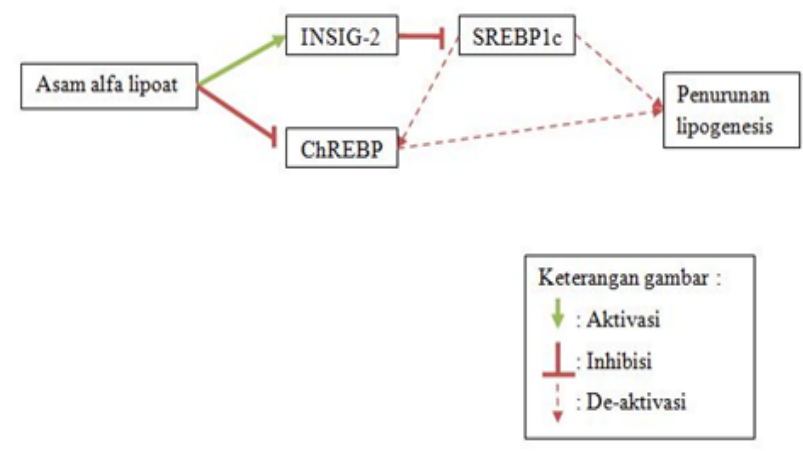

Gambar 1. Kerja ALA menurunkan kadar trigliserida ${ }^{6}$ INSIG2: insulin-induced gene 2 protein; ChREBP : carbohydrate responsive element binding protein; SREBP1-c:sterol regulatory element binding protein 1c. 


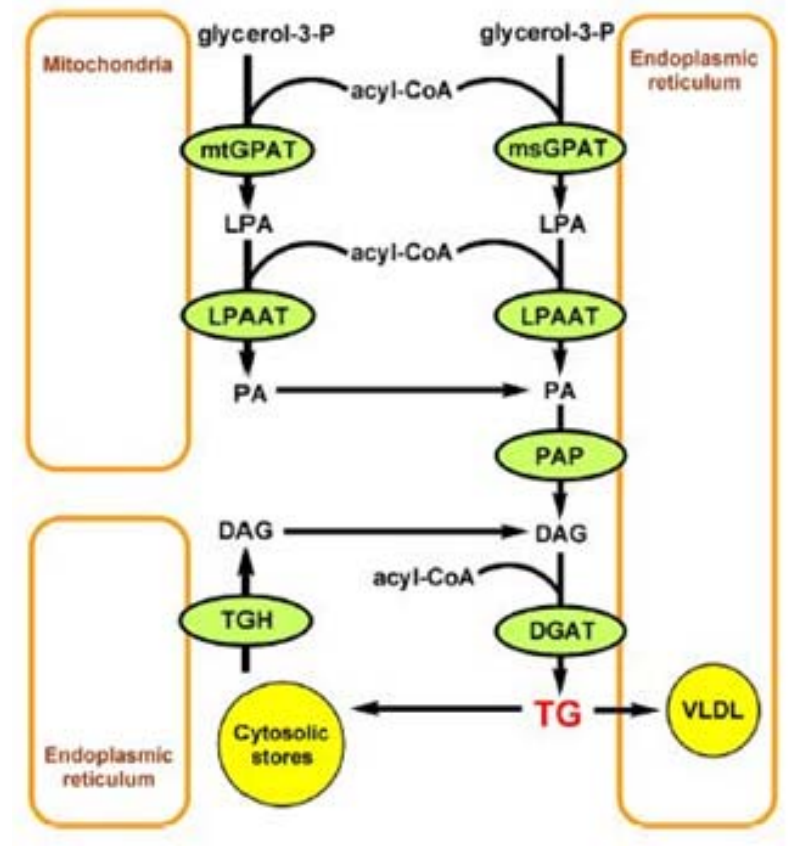

Gambar 2. Peran enzim GPAT dan DGAT dalam sintesis trigliserida serta kerja ChREBP dan SREBP1-c. ${ }^{7}$ mtGPAT, msGPAT :Mitochondrial, microsomal sn-glycerol-3phosphate acyltransferase; glycerol-3-P :sn-glycerol-3phosphate; acyl-CoA: acyl-coenzyme A; LPA: lysophosphatidic acid; TG : triglyceride; LPAAT: LPA acyltransferase; PA :phosphatidic acid; PAP : PA phosphatase; DGAT : diacylglycerol O-acyltransferase; DAG : diacylglycerol; VLDL : very low-density lipoprotein; TGH : Triglyceride hydrolase; ChREBP : carbohydrate responsive element binding protein; SREBP1-c:sterol regulatory element binding protein 1c.

Keadaan peningkatan trigliserida bisa disebabkan akibat peningkatan sekresinya di hati, penurunan pembersihan lipoprotein kaya trigliserida (VLDL, kilomikron, IDL), maupun kombinasi keduanya. ALA menurunkan kadar kilomikron setelah 2 jam pemberian dan menstimulasi pembersihan kilomikron setelah diberikan ALA secara intravena. ${ }^{6}$ Penelitian Butler et al, menunjukkan pemberian ALA menurunkan sekresi VLDL sampai $31 \%$ sehingga ALA juga dapat menurunkan kadar trigliserida melalui penghambatan jalur de novo di hati dan produksi VLDL. ${ }^{7}$ Meningkatnya aktivitas lipoprotein lipase juga berkontribusi terhadap penurunan partikel VLDL yang berdampak terhadap peningkatan LDL.
Selanjutnya peningkatan aktivitas lipase hati akan menyebabkan peningkatan hidrolisis trigliserida yang dihambat oleh resistensi insulin pada tikus DM tipe 2. Asam alfa lipoat ternyata juga dapat meningkatkan aktivitas lipoprotein lipase dan lipase hati. Carrier et al memberikan suplementasi ALA selama 30 hari pada tikus Zucker yang diberi diet tinggi lemak menunjukkan peningkatan aktivitas dari total lipase (lipoprotein lipase dan lipase hati) di serum dan otot skelet. ${ }^{18}$ Penelitian Thirunavukkarasu et al, menunjukkan ALA (35 mg/kgbb) selama 20 hari dapat meningkatkan aktivitas lipoprotein lipase pada tikus resistensi insulin yang diberi diet tinggi fruktosa. ${ }^{19}$ Dengan ditemukannya berbagai cara kerja ALA menurunkan kadar trigliserida maka ALA dapat digunakan sebagai pencegahan dan terapi hipertrigliseridemia pada diabetes melitus tipe 2 .

\section{KESIMPULAN}

Terdapat peningkatan kadar trigliserida secara bermakna pada kelompok DM tipe 2 dibandingkan kelompok kontrol dan pemberian ALA dapat mencegah peningkatan kadar trigliserida.

\section{DAFTAR PUSTAKA}

1. Diez JMB, Pennafiel J, Subirana I, Ramos R, Elosua R, Ibanez AM, et al. Risk of causespecific death in individuals with diabetes: A competing risks analysis. Diabetes Care. 2016;39(11):1987-95.

2. Badan Penelitian dan Pengembangan Kesehatan. Riset Kesehatan Dasar (RISKESDAS) 2013. Lap Nas 2013. 2013;1-384.

3. Gaede P, Oellgaard J, Carstensen B, Rossing P, Lund-Andersen $\mathrm{H}$, Parving $\mathrm{HH}$, et al. Years of life gained by multifactorial intervention in patients with type 2 diabetes mellitus and microalbuminuria: 21 years follow-up on the Steno-2 randomised trial. Diabetologia. 2016;59:2298-307.

4. Mihardja L, Soetrisno U, Soegondo S. Prevalence and clinical profile of diabetes mellitus in productive aged urban Indonesians. J Diabetes Investig. 2014;5(5):507-12. 
5. Soebardi S, Purnamasari D, Oemardi M, Soewondo P, Waspadji S, Soegondo S. Dyslipidemia in newly diagnosed diabetes mellitus: the Jakarta primary non-communicable disease risk factors surveillance 2006. Acta Med Indones. 2009;41(4):186-90.

6. Pashaj A, Xia M, Moreau R. á-Lipoic acid as a triglyceride-lowering nutraceutical. Can J Physiol Pharmacol. 2015;93(12):1029-41.

7. Butler JA, Hagen TM, Moreau R. Lipoic acid improves hypertriglyceridemia by stimulating triacylglycerol clearance and downregulating liver triacylglycerol secretion. Arch Biochem Biophys. 2009 May;485(1):63-71.

8. Heinisch BB, Francesconi M, Mittermayer F, Schaller G, Gouya G, Wolzt M, et al. Alpha-lipoic acid improves vascular endothelial function in patients with type 2 diabetes: A placebo-controlled randomized trial. Eur $\mathrm{J}$ Clin Invest. 2010;40(2):148-54.

9. Ismawati, Winarto, Sari R. Pencegahan lesi aterosklerosis oleh asam alfa lipoat pada aorta mencit jantan (Mus Musculus) yang diberi diet tinggi kolesterol. J Physiol Biochem. 2012;68:30718.

10. Annadurai T, Muralidharan AR, Joseph T, Hsu MJ, Thomas PA, Geraldine P. Antihyperglycemic and antioxidant effects of a flavanone, naringenin, in streptozotocin-nicotinamide-induced experimental diabetic rats. J Physiol Biochem. 2012;68(3):307-18.

11. Szkudelski T. Streptozotocin-nicotinamideinduced diabetes in the rat. Characteristics of the experimental model. Exp Biol Med. 2012;237(5):481-90.
12.Ghasemi A, Khalifi S, Jedi S. Streptozotocinnicotinamide-induced Rat Model of Type 2 Diabetes (review). Acta Physiol ogica Hungarica. 2014;101(4):408-20.

13. Tangvarasittichai S. Oxidative stress, insulin resistance, dyslipidemia and type 2 diabetes mellitus. World J Diabetes. 2015;6(3):456-80.

14. Murugan P, Pari L. Effect of tetrahydrocurcumin on lipid peroxidation and lipids in streptozotocinnicotinamide-induced diabetic rats. Basic Clin Pharmacol Toxicol. 2006;99(2):122-7.

15. Satheesh MA, Pari L. Effect of pterostilbene on lipids and lipid profiles in streptozotocin nicotinamide induced type 2 diabetes mellitus. $\mathrm{J}$ Appl Biomed. 2008;(June 2014):31-7.

16. Nekooeian AA, Eftekhari MH, Adibi S, Rajaeifard A. Effects of pomegranate seed oil on insulin release in rats with type 2 diabetes. Iran J Med Sci. 2014;39(2):130-5.

17.Hammond LE, Gallagher PA, Wang SL, Hiller S, Kluckman KD, Posey-Marcos EL, et al. Mitochondrial Glycerol-3-Phosphate Acyltransferase-Deficient Mice Have Reduced Weight and Liver Triacylglycerol Content and Altered Glycerolipid Fatty Acid Composition. Mol Cell Biol. 2002;22(23):8204-14.

18. Carrier B, Wen S, Zigouras S, Browne RW, Li $\mathrm{Z}$, Patel MS, et al. Alpha-lipoic acid reduces LDL-particle number and PCSK9 concentrations in high-fat fed obese Zucker rats. PLoS One. 2014;9(3).

19. Thirunavukkarasu V, Anitha Nandhini AT, Anuradha C V. Effect of á-lipoic acid on lipid profile in rats fed a high-fructose diet. Exp Diabesity Res. 2004;5(3):195-200. 